\title{
Preliminary studies on biological control of the blackpoint complex of wheat in Argentina
}

\author{
Cecilia Mónaco ${ }^{1,2, *}$, Marina Sisterna ${ }^{1,2}$, Analía Perelló ${ }^{1,3}$ and Gustavo Dal Bello ${ }^{1,2}$ \\ ${ }^{1}$ Centro de Investigaciones de Fitopatología (CIDEFI), Facultad de Ciencias Agrarias y Forestales, Universidad \\ Nacional de La Plata, 60 y 119, 1900 La Plata, Buenos Aires, Argentina \\ ${ }^{2} \mathrm{CIC}$ \\ ${ }^{3}$ CONICET \\ *Author for correspondence: Fax: +54-2214-252-346, E-mail: fitopato@ceres.agro.unlp.edu.ar
}

Received 19 May 2003; accepted 12 November 2003

Keywords: Alternaria alternata, biological control, Bipolaris sorokiniana, blackpoint, wheat

\begin{abstract}
Summary
Blackpoint is a brownish or black discoloration of wheat kernels and biological control is a complementary strategy to manage the disease. This work evaluated the effect of five strains of Trichoderma harzianum and one strain of $T$. koningii on the growth of Bipolaris sorokiniana and Alternaria alternata and compared the results of screening tests under controlled conditions and field evaluations on bread and durum wheat ears. Disease incidence, infection percentage and seedling emergence percentage determined in a greenhouse assay were evaluated. Dual cultures showed Trichoderma spp. inhibited significantly the mycelial growth of $B$. sorokiniana between 36 and $71 \%$ and of A. alternata between 41 and $61 \%$. Microscopic examination of B. sorokiniana and A. alternata showed plasmolysis and vacuolization of hyphae of the pathogens in the presence of the antagonists tested. With pre-inoculation of wheat ears at anthesis under field conditions, disease incidence, infection percentage by blotter tests and seedling emergence in the greenhouse did not show significant differences between controls and treatments with Trichoderma spp.
\end{abstract}

\section{Introduction}

Blackpoint is a brownish or black discoloration of wheat kernels that occurs at the germ end of the caryopsis which, in severe cases, extends along the crease and over the shoulders (kernel smudge). It occurs on cereal grains throughout all major wheat-growing areas of the world. The pathogens more frequently associated with it are Alternaria alternata and Bipolaris sorokiniana (Mathur \& Cunfer 1993). In addition, other fungi such as Fusarium, Curvularia, Cladosporium and Epicoccum can also parasitize wheat seed (Wiese 1987). The disease is known to adversely affect grain quality, impairing flour semolina and their products (King et al. 1981; Dexter \& Matsuo 1982).

Resistance to blackpoint is quite common in bread or durum wheats, but in the studies done up till now, no cultivars completely free of infection have been found (Conner \& Davidson 1988; Sisterna \& Sarandon 2000). Fungicide application is another alternative, but the controversial results reported by Conner \& Kuzyk (1988) and Mellado et al. (1990), the interaction of the disease with other factors such as nitrogen application (Gooding et al. 1993) and the need to minimize the release of pesticides to the environment in a sustainable agricultural context require a better understanding of the genotype $\times$ environment interactions of this disease in order to design adequate management strategies. A number of diseases of wheat are strongly influenced by $\mathrm{N}$ fertilization but the effect of available $\mathrm{N}$ on disease severity often varies with time of application, the form of $\mathrm{N}$ used and the disease (Huber 1980). Also, tillage methods change biological activity affecting nutrient release, especially nitrogen $(\mathrm{N})$ availability, and crop susceptibility to pathogens could be modified (Pearson et al. 1991; Sisterna \& Sarandon 1996).

Finally, black point development in wheat is influenced by irrigation, precipitation and length of dew period (Southwell et al. 1980). Heavy irrigation after flowering is complete, increases black point incidence in susceptible cultivars (Conner 1987).

The goal remains to integrate all available genetic, cultural, biological and chemical methods for disease control in a way to optimize their benefits and minimize their risks for producers, consumers and the environment (Cook \& Veseth 1991).

Several biological antagonists of Bipolaris sorokiniana and Alternaria alternata, isolated from leaves (Fokkema 
et al. 1975; Hodges et al. 1994) and soil (Turham 1993) have been identified. Among the antagonistic agents, Trichoderma spp. have been successfully used for biocontrol of pathogens on plant surfaces of cruciferous, solanaceous and gramineous plants (Rai \& Singh 1980; Scharen \& Bryan 1981; Tronsmo 1986; Kumar \& Singh 1985; Elad \& Kirschner 1993; Sutton \& Peng 1993; Michereff et al. 1995). The diversity of mechanisms available to Trichoderma spp. for pathogen suppression (e.g., production of a wide range of broad-spectrum antifungal metabolites, mycoparasitism, and competition with pathogen for nutrients and for occupation of the infection court and crop residue) make these fungi attractive biocontrol agents. In this sense there are some records on the potential biocontrol of Trichoderma isolates on B. sorokiniana (Biles \& Hill 1988). In Argentina Dal Bello et al. (1994) evaluated the supression of wheat seedling blight caused by $B$. sorokiniana using some Trichoderma isolates. No previous records of antagonism between Trichoderma spp. and the more frequently pathogens associated to blackpoint have been found. In this sense, the contribution of this paper is significant.

Thus in the preliminary study reported here, selected strains of $T$. harzianum and T. koningii were assessed to act as biocontrol agents against Bipolaris sorokiniana and Alternaria alternata, members of the complex of blackpoint on the wheat ear in Argentina, and the results of screening tests under laboratory and field conditions have been compared.

\section{Materials and methods}

\section{Pre-screening of fungal isolates of the pathogens}

Bipolaris sorokiniana and Alternaria alternata were originally isolated from naturally infected wheat seeds. In order to evaluate the pathogenicity of the isolates to wheat, artificial infection experiments were established. Pathogenicity of each isolate was confirmed by determining its ability to infect wheat heads of cv. Buck Poncho (a susceptible cultivar). Plants were grown from seeds of cv. Buck Poncho and ears were inoculated at anthesis with spore suspensions of fungal isolates of $B$. sorokiniana and $A$. alternata (250,000 conidia $\left.\mathrm{ml}^{-1}\right)$. Ears showed symptoms of blackpoint after 7 days and pathogenic isolates of both fungi were maintained on tubes of PDA at $5{ }^{\circ} \mathrm{C}$ in the dark and used to the assays.

\section{Isolates and cultures of the antagonists}

Five strains of Trichoderma harzianum (Th3, Th7, Th9, Th10, Th12) and one strain of $T$. koningii (Tk4) were isolated from horticultural soil using the soil dilution technique (Dal Bello 1982). The pathogens and the antagonists were maintained in potato dextrose agar (PDA) medium at $5{ }^{\circ} \mathrm{C}$ until use.

\section{In vitro antagonistic activity assays}

The antagonistic activity of the strains of Trichoderma was tested in vitro using $90 \mathrm{~mm}$ Petri dishes containing $15 \mathrm{ml}$ of PDA medium, $\mathrm{pH}$ 6.5. Disks (6 mm-diameter) from colony margins of each pathogen-antagonist combination were placed at a distance of $35 \mathrm{~mm}$ apart. Control consisted in individual cultures of the pathogen. Each dual culture (pathogen-antagonist) had five replications. The plates were incubated at $20-22{ }^{\circ} \mathrm{C}$ with light alternancy (3500 lux dark cycles of $12 \mathrm{~h}$ plus the addition of near u.v. light $(365 \mathrm{~nm}))$. After 8 days, the plates were evaluated for antagonistic activity, considering the ability of the microorganisms to reduce pathogen colony expansion. Additionally, microscopic examinations of the area of intermingling growth (pathogen-antagonist) were also considered.

\section{Field assays}

To determine the antagonism of the Trichoderma spp. against the pathogens, ears of bread wheat (Triticum aestivum L.) of cultivar Buck Poncho and ears of durum wheat ( $T$. durum Desf.) of cultivar Bonaerense INTA Cummenay, were tested. The assay was conducted at the Estación Experimental J. Hirschhorn, belonging to the Facultad de Ciencias Agrarias y Forestales de la Universidad Nacional de La Plata in October-November 2001.

For inoculation, Trichoderma strains and the pathogens were cultured on PDA medium in Erlenmeyer flasks and incubated for $7-15$ days at $20 \pm 2{ }^{\circ} \mathrm{C}$ in a growth chamber under $12 \mathrm{~h}$ fluorescent plus near ultraviolet (u.n.v.) photoperiod. Conidia of each isolate were harvested by flooding the cultures with sterile distilled water and then rubbing the culture surfaces with a sterile glass rod. After filtering the suspensions through two layers of cheesecloth, concentrations of propagules in suspensions were standarized with the aid of a haemocytometer to $1 \times 10^{8}$ conidia per $\mathrm{ml}$ for the Trichoderma isolates tested. The concentration of $B$. sorokiniana and A. alternata was $3 \times 10^{5}$ spores $\mathrm{ml}^{-1}$. All suspensions were amended with one drop of $0.05 \%$ Tween 80 surfactant in distilled water inmediately before plant inoculation. At the flowering stage of bread and durum wheat, the antagonists were applied on 10 wheat heads (experimental unit). Following these treatments, the test plants were incubated for $24 \mathrm{~h}$ in large transparent [polyethylene] bags to maintain high relative humidity. After $24 \mathrm{~h}$, the plastic bags were opened for $30 \mathrm{~min}$ before both pathogens, B. sorokiniana and $A$. alternata were applied on the ears separately. Plants were resealed in plastic bags for $48 \mathrm{~h}$ to encourage symptoms development. All the microorganisms suspension were sprayed until run-off using a manually operated sprayer. Control plants were either sprayed with water and inoculated with $B$. sorokiniana or $A$. alternata spores suspensions or sprayed twice with water. After bag removal, ears were examined daily to 
establish the incubation period (time from inoculation to appearance of first symptoms) for each treatments. At maturity, all plants were hand-harvested and the disease was assessed.

A randomized block design with four replications was used for each experimental unit. All the spikes treated were evaluated and compared to the controls.

\section{Assessment of antagonism}

After harvest, with the grains recolected the following parameters were evaluated:

(a) Disease incidence (defined as the percentage of discoloured wheat seeds) regarding a sample of 200 seeds per treatment in four replications.

(b) Infection percentage. Seeds (200 per treatment in four replications) were subjected to the blotter test following the ISTA rules (Neergaard 1974) to determine kernel infection by $B$. sorokiniana and $A$. alternata. Samples were observed after 7 days.

(c) Seedling emergence. The percentage of seedlings emerged was determined under greenhouse conditions over 200 seeds per treatment maintained in plastic trays of $15 \times 30 \mathrm{~cm}$.

Data of each of the experiments were analysed by an analysis of variance (ANOVA) and means were compared by Tukey test $(p=0.05)$.

\section{Results}

In vitro antagonistic activity assays

There were significant differences between some Trichoderma isolates tested on the percentage inhibition of the mycelial growth of both pathogens (Figure 1). For A. alternata the percentage inhibition compared with the control varied between 41 for isolate Th7 and 61 for isolate Th10. In the case of $B$. sorokiniana these values were between 36 for isolate Th7 and 71 for isolate Th9.

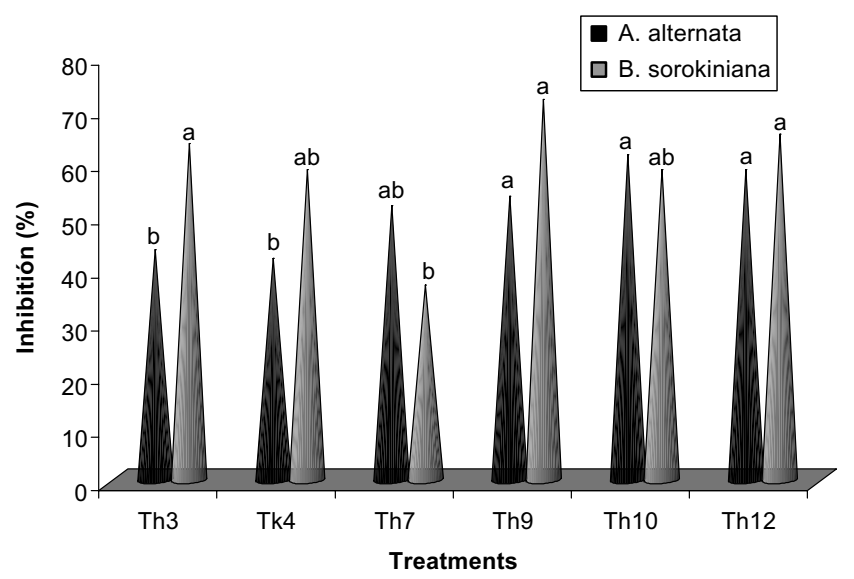

Figure 1. Percentage of inhibition of the colony diameter of Alternaria alternata and Bipolaris sorokiniana by Trichoderma strains 'in vitro'.

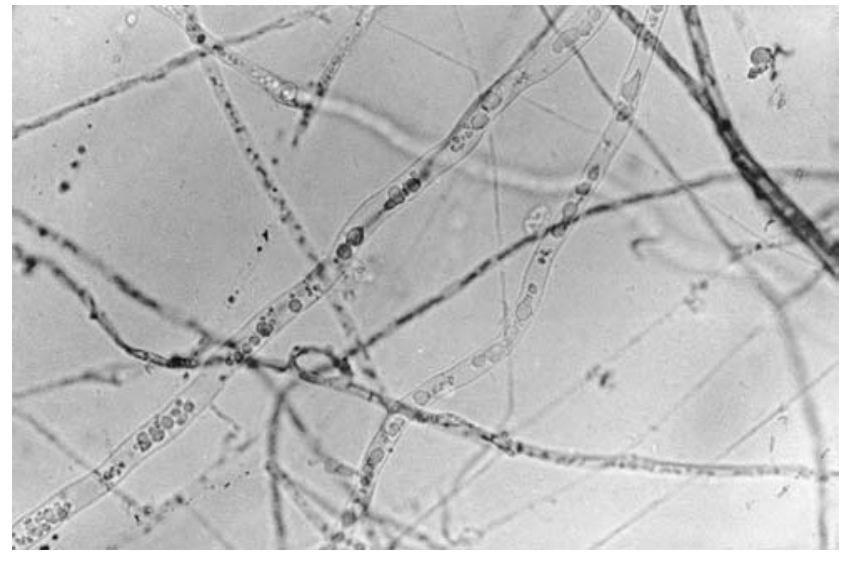

Figure 2. Vacuolated and plasmolyzed mycelium of B. sorokiniana in the presence of T. harzianum (Th7) $(\times 400)$.

All Trichoderma isolates tested overgrew the pathogen colonies completely.

Microscopic examination of cultures of Trichoderma spp. and A. alternata or B. sorokiniana in close proximity showed differences in hyphal morphology of the pathogen among treatments and the control. In the combination T. harzianum (Th7) and B. sorokiniana vacuolization of hyphae and plasmolysis of mycelium was observed (Figure 2).

Mycelium showing a torulose aspect was noticed in the combination of T. harzianum (Th10) and B. sorokiniana (Figure 3).

In addition, coiling was observed due to the antagonism of T. harzianum (Th9) on B. sorokiniana (Figure 4) and $A$. alternata (Figure 5).

\section{Assessment of antagonism in the field}

No antagonistic effect on A. alternata and B. sorokiniana incidence was evidenced for any of the Trichoderma spp. strains tested either on bread (Figure 6) or durum (Figure 7) wheat ears. For both pathogens there were no significative differences in the infection percentage in the treatments with the antagonists respect to the controls.

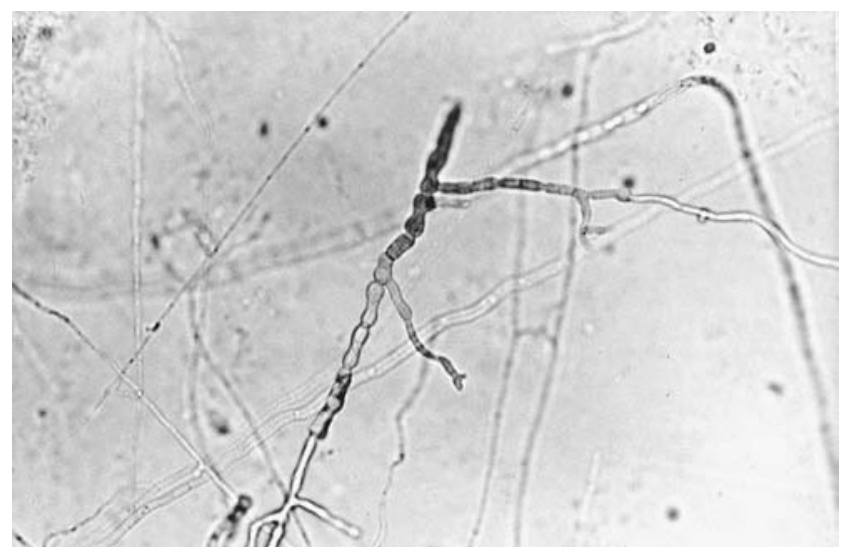

Figure 3. Mycelium of B. sorokiniana showing torulose aspect with T. harzianum $(\mathrm{Th} 10)(\times 400)$. 


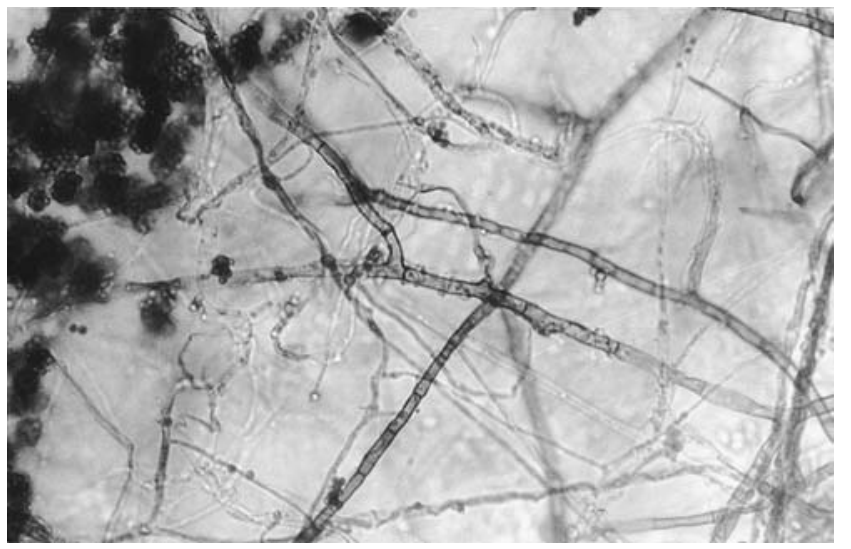

Figure 4. Coiling due to the antagonism of T. harzianum (Th9) on $B$. sorokiniana $(\times 400)$.

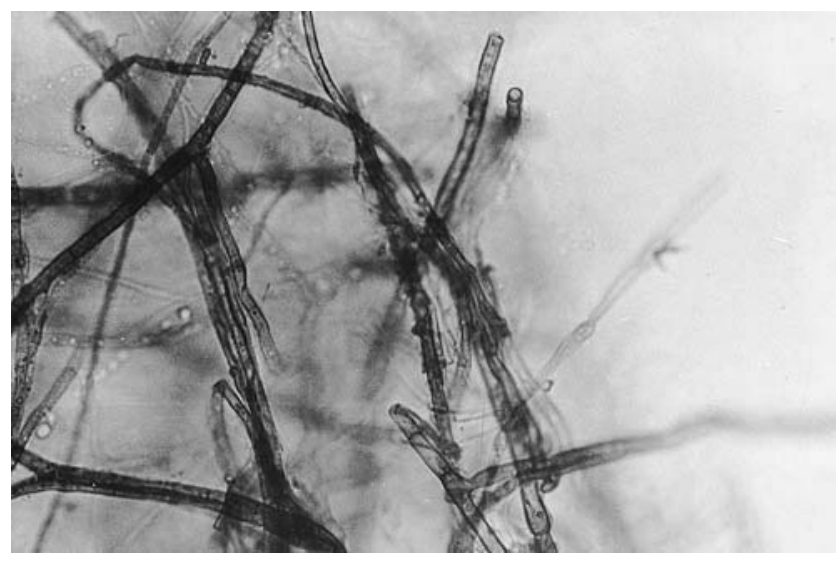

Figure 5. Coling between T. harzianum (Th9) and A. alternata $(\times 400)$

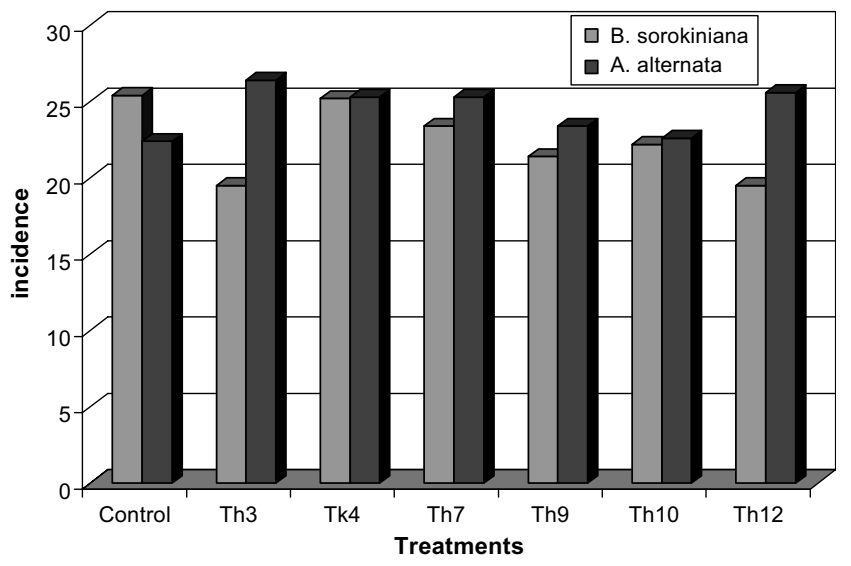

Figure 6. Disease incidence in common wheat.

However, the $A$. alternata contamination in bread wheat decreased between 10 and $66 \%$ in the Th3 and Th12 treatments respectively (Figure 8).

In the greenhouse, the results of the wheat seedling emergency did not show significative differences between controls and the bread and durum wheat seeds treated with Trichoderma spp. strains (Figures 9 and 10).

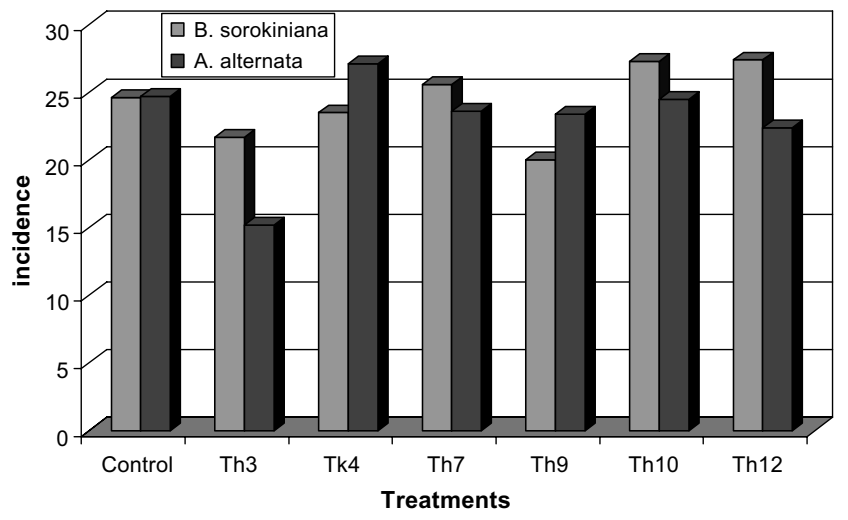

Figure 7. Disease incidence in durum wheat.

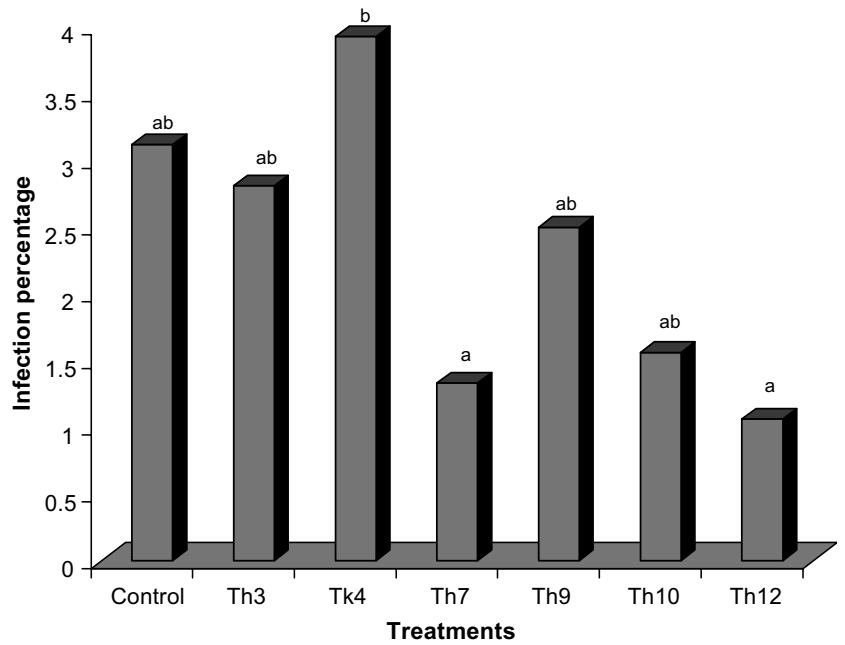

Figure 8. Infection percentage by A. alternata in common wheat seeds.

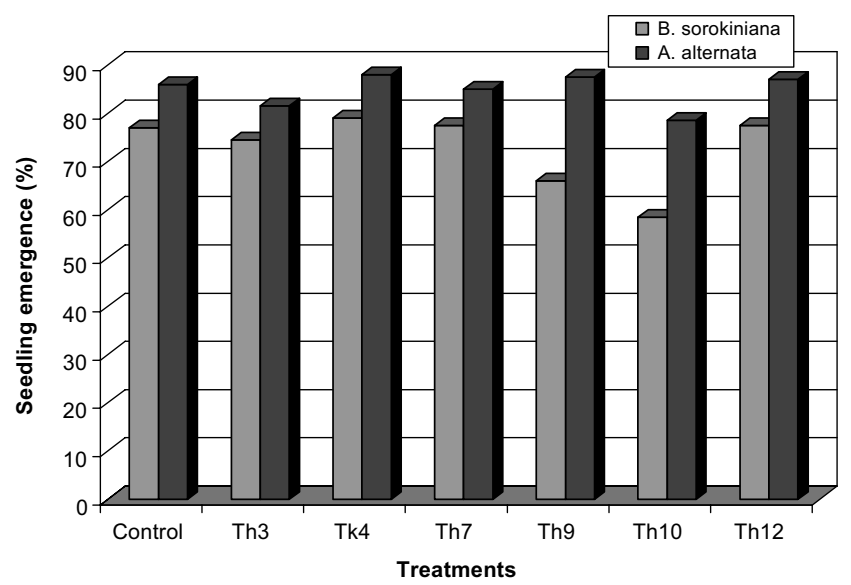

Figure 9. Seedling emergence percentage on common wheat in a greenhouse assay.

\section{Discussion}

No durable resistance to the disease currently exists, and the control of blackpoint relies on an integrated combination of cultural management (Conner et al. 


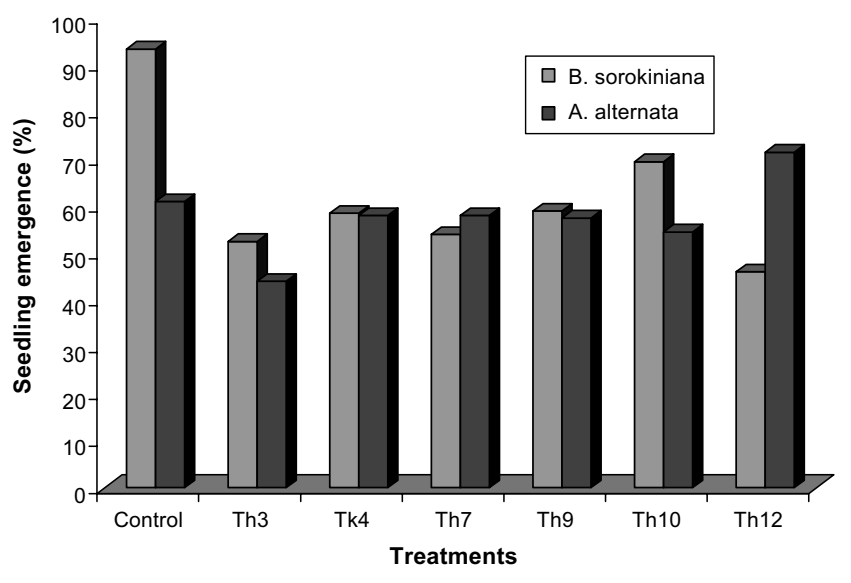

Figure 10. Seedling emergence percentage on durum wheat in a greenhouse assay.

1992; Gooding et al. 1993), fungicides (Conner \& Kuzyk 1988; Ellis et al. 1996) and the use of partially resistant or tolerant cultivars (Conner \& Davidson 1988; Sisterna \& Sarandon 2000). A complementary strategy within the integrated management is the possibility of biological control. Interest in biological control research continues, reflecting the desire to develop sustainable methods for controlling plant diseases. With the introduction of the biological control for cereal crops, an additional tool is available for the design of more sustainable disease control strategies.

Members of the fungal genus Trichoderma have been extensively studied, particularly due to their ability to act as biocontrol agents (Papavizas 1985; Melo 1991). In our work, most of the isolates tested belonged to $T$. harzianum, which has been widely reported as a biocontrol agent in the aerial environment (Lewis \& Papavizas 1991; Haran et al. 1996a, b; Elad 2000; Hermosa et al. 2000). There are no records of this fungal species at saprophytic state in wheat head but it was isolated from phylloplane (Perelló et al. 2001) and as endophyte (Larrán et al. 2002).

From this preliminary study, the results of the tests conducted in vitro suggest that the competition could be the mode of action of the Trichoderma strains tested. Trichoderma strains quickly colonized Petri dishes, overgrowing the pathogens colonies, with the ability to exclude them. Microscopical observation of the dual cultures revealed morphological effects of the antagonists on the pathogens, such as vacuolization of hyphae, plasmolysis of mycelium and mycelium showing torulose aspect. Similar results were obtained by Perelló et al. (2003) who observed the effect of Trichoderma spp. on another Dematiaceae (Drechslera tritici-repentis) affecting wheat leaves.

In the field assay there were no significative differences among treatments. In most of the combinations the values registered were higher than the control.

The data presented in this paper suggest that certain biocontrol strategies may provide a practical alternative for the control of blackpoint in wheat crops. However, typically antagonistic fungi are most effective within a narrow band of environmental conditions, and since in vitro or glasshouse experiment is exposed to less extreme conditions that outdoor crops, it is to be expected that any artificially introduced agent would have more success in a more controlled environment.

The tremendous environmental differences between the in vitro tested conditions and the field might explain the lack of positive results under field conditions.

The role of mycoflora as a control factor in blackpoint development, warrants further consideration, as it may be possible to reduce disease incidence by manipulating populations of benefical saprophytes on the head of wheat.

\section{References}

Biles, C. \& Hill, J. 1988 Effect of Trichoderma harzianum on sporulation of Cochliobolus sativus on excised wheat seedling leaves. Phytopathology 78, 656-659.

Conner, R. 1987 Influence of irrigation timing on black point incidence in soft white spring wheat. Canadian Journal of Plant Patholology 9, 301-306.

Conner, R. \& Davidson, G. 1988 Resistance in wheat to black point caused by Alternaria alternata and Cochliobolus sativus. Canadian Journal of Plant Science 68, 351-359.

Conner, R. \& Kuzyk, A. 1988 Effectiveness of fungicides in controlling stripe rust, leaf rust, and black point in soft white spring wheat. Canadian Journal of Plant Pathology 10, 321-326.

Conner, R., Carefoot, J., Bole, J. \& Kozub, G. 1992 The effect of nitrogen fertilizer and irrigation on black point incidence in soft white spring wheat. Plant and Soil 140, 41-47.

Cook, R. \& Veseth, J. 1991 Wheat health management. Plant Health Series. St. Paul, Minn. American Phytopathological Society Press ISBN 0-89054111-6.

Dal Bello, G. 1982 Selección de dos medios de cultivo adaptados al aislamiento de hongos de suelo. In Proceedings $2^{\circ}$ Congreso Latinoamericano de Fitopatología. Buenos Aires pp. 2-52.

Dal Bello, G., Mónaco, C. \& Sisterna, M. 1994 Efecto de Trichoderma spp sobre el control del tizón de la plántula del trigo ocasionado por Bipolaris sorokiniana bajo condiciones de invernáculo. Fitopatología Brasileira 19, 394-400.

Dexter J.E. \& Matsuo R.R. 1982 Effect of smudge and blackpoint, mildewes kernels and ergot on durum wheat quality. Cereal Chemistry 59, 63-69.

Elad, Y. 2000 Biological control of foliar pathogens by means of $T$. harzianum and potential modes of action. Crop Protection 19, 709714.

Elad, Y. \& Kirschner, B. 1993 Survival in the phylloplane of an introduced biocontrol agent (Trichoderma harzianum) and population of the plant pathogen Botrytis cinerea as modified by abiotic conditions. Phytoparasitica 21, 303-313.

Ellis, S., Gooding, M. \& Thompson, A. 1996 Factors influencing the relative susceptibility of wheat cultivars (Triticum aestivum L.) to blackpoint. Crop Protection 15, 69-76.

Fokkema, N., Van de Laar, A., Nelis-Blomerg, A. \& Schippers, B. 1975 The buffering capacity of the natural mycoflora of rye leaves to infection by Cochliobolus sativus, and its susceptibility to benomyl. Netherlands Journal of Plant Pathology 81, 176-186.

Gooding, M., Thompson, F., Collingborn, S., Smith, S. \& Davies, W. 1993 Blackpoint on wheat grain: influences of cultivar, management and season on symptom severity. Aspects of Applied Biology 36, 391-396. 
Haran, S., Schikler, H. \& Chet, I. 1996a Molecular mechanisms of lytic enzymes involved in the biocontrol activity of Trichoderma harzianum. Microbiology 142, 2321-2331.

Haran, S., Schikler, H., Oppenheim, A. \& Chet, I. 1996b Differential expression of Trichoderma harzianum chitinases during mycoparasitism. Phytopathology 86, 981-985.

Hermosa, M.R., Grondona, I., Iturriaga, E.A., Díaz-Minguez, J.M., Castro, C., Monte, E. \& García-Acha, I. 2000 Applied and Environmental Microbiology 66, 1890-1898.

Hodges, C., Campbell, D. \& Christians, N. 1994 Potential biocontrol of Sclerotinia homeocarpa and Bipolaris sorokiniana on the phylloplane of Poa pratensis with strains of Pseudomonas spp. Plant Patholology 43, 500-506.

Huber D.M. 1980 The role of mineral nutrition in defense. In Plant Disease, vol 5, pp. 381-406, New York, Academic Press. ISBN 012-356405-0.

King, J.E., Evers, A.D. \& Stewart, B.A. 1981 Black point of grain in spring wheats of the 1978 harvest. Plant Pathology 30, 51-53.

Kumar, K. \& Singh, H. 1985 In vitro antagonistic studies between Alternaria solani and saprophytic mycoflora isolated from potato leaves. Indian Journal of Mycology and Plant Pathology 13, 24-27.

Larrán, S., Perelló, A., Simón, M.R. \& Moreno, V. 2002 Isolation and analysis of endophytic microorganisms in wheat (Triticum aestivun L.) leaves. World Journal of Microbiology and Biotechnology 18, 683-686.

Lewis, J.A. \& Papavizas, G.C. 1991 Biocontrol of plant diseases: the approach for tomorrow. Crop Protection 10, 95-105.

Mathur S.B. \& Cunfer B. 1993 Blackpoint. In Seed-borne Diseases and Seed Health Testing of Wheat, eds. Mathur, S.B. \& Cumfer, B.M. First edition. Danish Government Institute of Seed Pathology for Developing Countries, Copenhagen, Denmark, pp. 13-21. ISBN 877026329-9.

Mellado M., France, A. \& Matus, I. 1990 Efecto de fungicidas sobre el problema 'punta negra', en trigo de primavera (Triticum aestivum L.), sembrado en suelos regados de la zona centro sur de Chile. Agricultura Técnica 50, 71-75.

Melo, Y. 1991 Potencialidades de utilizacao de Trichoderma spp no controle biológico de doencas de plantas. In Controle biológico de doencas de plantas. EMBRAPA, Brasilia, DF, pp. 388, Cap 9, 135 156.

Michereff, N., Da Siveira, S., Reis, A. \& Mariano, R. 1995 Greenhouse screening of Trichoderma isolates for control of Curvularia leaf spot of yam. Mycopathology 130, 103-108.

Neergaard, P. 1974 Report of the IV Workshop Regional on Seed Pathology for Developing countries. Danish Government Institute of Seed Pathology, Copenhagen.
Papavizas, G.C. 1985 Trichoderma and Gliocladium: Biology, ecology and potencial for biocontrol. Annual Review of Phytopathology 23, 23-54.

Pearson, C.J., Mann I.G. \& Zianhua Z. 1991 Changes in root growth within succesive wheat crops in a cropping cycle using minimum and conventional tillge. Field Crop Reseach 28, 117133.

Perelló, A., Simón, M., Sisterna, M., Cordo, C. \& Arambarri, A. 2001 Microflora of wheat (Triticum aestivum L.) in Buenos fAires Province (Argentina) and its possible significance in biological control of foliar pathogens. Journal of Plant Disease and Protection 108, 459-471.

Perelló, A., Mónaco, C., Sisterna, M. \& Dal Bello, G. 2003 Biocontrol efficacy of Trichoderma isolates for Tan Spot of wheat in Argentina. Crop Protection 22, 1099-1106.

Rai, B. \& Singh 1980 Antagonistic activity of some leaf surface microfungi against Alternaria brassicae and Drechslera graminea. Transactions of the British Mycological Society 75, 363369.

Scharen, A. \& Bryan, D. 1981 A possible control agent for net blotch of barley. Phytopathology 71, 902-903.

Sisterna, M. \& Sarandón, S. 1996 Blackpoint of wheat (Bipolaris sorokiniana (Sacc.) Shoem influenced by $\mathrm{N}$ fertilization under no till and conventional tillage. Cereal Research Communications 24, 217-221.

Sisterna, M. \& Sarandón, S. 2000 Blackpoint incidence on durum wheat in Argentina: influence of cultivar and location. Acta Agronomica Hungarica 48, 395-401.

Southwell, R., Brown, J. \& Wong, P. 1980 Effect of inoculum density, stage of plant growth and dew period on the incidence of black point caused by Alternaria alternata in durum wheat. Annals of Applied Biology 96, 29-35.

Sutton, J. \& Peng, G. 1993 Manipulation and vectoring of biocontrol organisms to manage foliage and fruit diseases in cropping systems. Annual Review of Phytopathology 31, 473-479.

Tronsmo, A. 1986 Use of Trichoderma spp. in biological control of necrotrophic pathogens. In Microbiology of the Phyllosphere. eds. Fokkema, N. \& Der Heuvel, J. Cambridge: Cambridge University Press, 1986. ISBN 0-521-32344-4.

Turhan, G. 1993 Mycoparasitism of Alternaria alternata by additional eight fungi indicating the existence of further unknown candidates for biological control. Journal of Phytopathology 138, 283291.

Wiese, M.V. 1987 In Compendium of Wheat Diseases, ed. Wiese, M.V. 2nd edn. St. Paul, Minnesota: American Phytopathological Society. ISBN 0-89054076-4. 